\title{
Gambaran Pengetahuan Tentang Hak dan Kewajiban Pasien Rawat Inap di Rumah Sakit Umum PKU Muhammadiyah Sragen
}

\author{
Ayuk Aji Pratiwi', Antik Pujihastuti² \\ STIKes Mitra Husada Karanganyar \\ ayukaji97@gmail.com, att2a2000@yahoo.com,
}

\begin{abstract}
Based on introduction survey result by deploy questionnaire it can be known that from 15 inpatient who as respondent, there are 5 (33\%) respondent have less knowledge about authority on medicines secret and 2 (13\%) respondent have less knowledge about patient duty. The objective of research is to know visible image of patient knowledge about authority and duty inpatient at Rumah Sakit Umum PKU Muhammadiyah Sragen. The kind of this research is descriptive. The research variable is patient knowledge on patient authority and patient knowledge on patient duty. The population and sample of research is inpatient at Rumah Sakit Umum PKU Muhammadiyah Sragen. The technique of take the sample by sample purposive technique. The instrument of research is closed questionnaire. The technique of processing data includes Collecting, Editing, Scoring, Coding, Tabulating, and Data Presentation. The data analysis is in a descriptive manner. The result of research shows that most of patient knowledge on authority medical information is good category (64\%) and partly little is fewer categories (13\%). Most of patient knowledge about authority to give approval medical action is good category (60\%) and partly little is fewer categories (15\%). Most of patient knowledge about authority on medicines secret is good category (39\%) and partly little is fewer categories (28\%). Most of patient knowledge about authority on second opinion is good category (52\%) and partly little is fewer categories (18\%). Most of patient knowledge about patient duty to hospital is good category (68\%) and partly little is fewer categories (8\%).
\end{abstract}

Key word: Patient knowledge, Patient authority, Patient duty

\begin{abstract}
ABSTRAK
Berdasarkan hasil survei pendahuluan dapat diketahui bahwa dari 15 pasien rawat inap yang dijadikan responden, terdapat $5(33 \%)$ responden memiliki pengetahuan kurang tentang hak atas rahasia kedokteran dan $2(13 \%)$ responden memiliki pengetahuan kurang tentang kewajiban pasien. Tujuan penelitian ini adalah mengetahui gambaran pengetahuan pasien tentang hak dan kewajiban pasien rawat inap di Rumah Sakit Umum PKU Muhammadiyah Sragen. Jenis penelitian ini deskriptif. Variabel penelitian adalah pengetahuan pasien tentang hak pasien dan pengetahuan pasien tentang kewajiban pasien. Populasi dan sampel penelitian yaitu pasien rawat inap di Rumah Sakit Umum PKU Muhammadiyah Sragen. Teknik pengambilan sampel dengan teknik purposive sampel. Instrumen penelitian adalah kuesioner tertutup. Analisis data dilakukan secara diskriptif. Hasil penelitian menunjukkan bahwa pengetahuan pasien tentang hak atas informasi medis sebagian besar adalah kategori baik (64\%) dan sebagian kecil adalah kategori kurang (13\%). Pengetahuan pasien tentang hak memberikan persetujuan ttindakan medis sebagian besar adalah kategori baik (60\%) dan sebagian kecil adalah kategori kurang (15\%). Pengetahuan pasien tentang hak atas rahasia kedokteran sebagian besar adalah kategori baik (39\%) dan sebagian kecil adalah kategori kurang (28\%). Pengetahuan pasien tentang hak atas pendapat kedua sebagian besar adalah kategori baik (52\%) dan sebagian kecil adalah kategori kurang (18\%). Pengetahuan pasien tentang kewajiban pasien terhadap rumah sakit sebagian besar adalah kategori baik (68\%) dan sebagian kecil adalah kategori kurang (8\%). Simpulan penelitian ini adalah hampir lebih dari $40 \%$ pasien tidak mempunyai pengetahuan yang baik tentang hak dan kewajiban pasien di rumah sakit.
\end{abstract}

Kata kunci: Pengetahuan pasien, hak pasien, kewajiban pasien 


\section{PENDAHULUAN}

Menurut Undang-Undang No. 44 Tahun 2009 Rumah Sakit adalah institusi pelayanan kesehatan yang menyelenggarakan pelayanan kesehatan perorangan secara paripurna yang menyediakan pelayanan rawat inap, rawat jalan, dan gawat darurat. Dalam pelayanan kesehatan, setiap pasien mempunyai hak dan kewajiban sebagai pasien di rumah sakit.

Hak dan Kewajiban pasien diatur dalam UndangUndang No. 36 tahun 2009 tentang Kesehatan. Macam-macam hak pasien meliputi hak atas informasi, hak memberikan persetujuan tindakan medis, hak atas rahasia kedokteran dan hak atas pendapat kedua. Sedangkan kewajiban pasien adalah memberikan informasi yang benar kepada dokter, mematuhi anjuran dokter atau perawat, memberi imbalan jasa yang layak dan tidak memaksakan keinginannya agar dilaksanakan oleh dokter apabila berlawanan dengan kebebasan dan keluhuran profesi dokter.

Secara formal penyedia pelayanan kesehatan khususnya Rumah Sakit mengakui bahwa pasien mempunyai hak dan kewajiban, tetapi kebanyakan pasien dan petugas kesehatan belum mengetahui hak dan kewajiban tersebut. Hal ini ditunjukkan dari hasil penelitian Yani (2011) dengan judul Tingkat Pengetahuan Pasien Tentang Hak dan Kewajiban Pasien Atas Informasi Medis Pasien Rawat Inap Kelas III di Rumah Sakit PKU Muhammadiyah Karanganyar menunjukkan bahwa sebagian besar adalah tingkat pengetahuan kurang 15 (50,0\%) responden dan sebagian kecil adalah tingkat pengetahuan baik $3(10,0 \%)$ responden.

Berdasarkan hasil survei pendahuluan dengan menyebarkan kuesioner dapat diketahui bahwa dari 15 pasien rawat inap yang dijadikan responden, terdapat $5(33 \%)$ responden memiliki pengetahuan kurang tentang hak atas rahasia kedokteran dan 2 $(13 \%)$ responden memiliki pengetahuan kurang tentang kewajiban pasien. Sehubungan dengan hal tersebut, penulis tertarik untuk melakukan penelitian dengan judul "Gambaran Pengetahuan Pasien Tentang Hak Dan Kewajiban Pasien Rawat Inap Di Rumah Sakit Umum PKU Muhammadiyah Sragen”.

\section{METODE}

Jenis penelitian yang digunakan adalah deskriptif yaitu menggambarkan pengetahuan pasien tentang hak dan kewajiban pasien rawat inap di Rumah Sakit Umum PKU Muhammadiyah Sragen. Populasi pada penelitian ini adalah 471 pasien rawat inap, dengan besar sampel 118 pasien rawat inap. Teknik pengambilan sampel yaitu purposive sampel. Instrumen penelitian yaitu kuesioner tertutup. Analisis data menggunakan analisis diskriptif.

\section{HASIL}

Karakteristik Pasien Rawat Inap

Tabel 1

Karakteristik Pasien Rawat Inap Berdasarkan Umur dan Tingkat Pendidikan di Rumah Sakit Umum PKU Muhammadiyah Sragen

\begin{tabular}{llcc}
\hline Variabel & Kategori & $\begin{array}{c}\text { Jumlah } \\
\text { Responden }\end{array}$ & $\begin{array}{c}\text { Presentase } \\
(\mathbf{\%})\end{array}$ \\
Umur & Remaja & 24 & 20 \\
& Dewasa & 39 & 33 \\
\multirow{5}{*}{ Pendidikan } & Manula & 55 & 47 \\
& SD & 30 & 25 \\
& SMP & 33 & 28 \\
& SMA & 39 & 33 \\
& Perguruan & 16 & 14 \\
& Tinggi & & \\
\hline
\end{tabular}

Pengetahuan Pasien Rawat Inap Tentang Hak Atas Informasi Medis

Tabel 2

Pengetahuan Pasien Rawat Inap Tentang Hak Atas Informasi Medis di Rumah Sakit Umum PKU Muhammadiyah Sragen

\begin{tabular}{lcc}
\hline \multicolumn{1}{c}{ Kategori } & $\begin{array}{c}\text { Jumlah } \\
\text { Responden }\end{array}$ & Persentase (\%) \\
\hline Baik & 75 & 64 \\
Cukup & 28 & 25 \\
Kurang & 15 & 13 \\
\hline Jumlah & 118 & 100 \\
\hline
\end{tabular}

Berdasarkan tabel 4.2 menunjukkan bahwa pengetahuan pasien rawat inap tentang hak atas informasi medis sebagian besar adalah kategori baik (64\%) dengan umur dewasa (26-45 tahun) dan pendidikan SMA, sedangkan sebagian kecil adalah kategori kurang (13\%) dengan umur dewasa (26-45 tahun) dan pendidikan SD. 
Pengetahuan Pasien Rawat Inap Tentang Hak Memberikan Persetujuan Tindakan Medis

Tabel 3

Pengetahuan Pasien Rawat Inap Tentang Hak Memberikan Persetujuan Tindakan Medis di Rumah Sakit Umum PKU Muhammadiyah Sragen

\begin{tabular}{lcc}
\hline \multicolumn{1}{c}{ Kategori } & $\begin{array}{c}\text { Jumlah } \\
\text { Responden }\end{array}$ & Persentase (\%) \\
\hline Baik & 71 & 60 \\
Cukup & 29 & 25 \\
Kurang & 18 & 15 \\
\hline Jumlah & 118 & 100 \\
\hline
\end{tabular}

Berdasarkan tabel 4.3 menunjukkan bahwa pengetahuan pasien rawat inap tentang hak memberikan persetujuan tindakan medis di Rumah Sakit Umum PKU Muhammadiyah Sragen sebagian besar adalah kategori baik (60\%) dengan umur dewasa (26-45 tahun) dan pendidikan SMA, sedangkan sebagian kecil adalah kategori kurang (15\%) dengan umur dewasa (26-45 tahun) dan pendidikan SD/SMP.

Pengetahuan Pasien Rawat Inap Tentang Hak Atas Rahasia Kedokteran

Tabel 4

Pengetahuan Pasien Rawat Inap Tentang Hak Atas Rahasia Kedokteran di Rumah Sakit Umum PKU Muhammadiyah Sragen

\begin{tabular}{lcc}
\hline \multicolumn{1}{c}{ Kategori } & $\begin{array}{c}\text { Jumlah } \\
\text { Responden }\end{array}$ & Persentase (\%) \\
\hline Baik & 46 & 39 \\
Cukup & 39 & 33 \\
Kurang & 33 & 28 \\
\hline Jumlah & 118 & 100 \\
\hline
\end{tabular}

Berdasarkan tabel 4 menunjukkan bahwa pengetahuan pasien rawat inap tentang hak atas rahasia kedokteran di Rumah Sakit Umum PKU Muhammadiyah Sragen sebagian besar adalah kategori baik (39\%) dengan umur dewasa (26-45 tahun) dan pendidikan SMA, sedangkan sebagian kecil adalah kategori kurang (28\%) dengan umur lansia (46-65 tahun) dan pendidikan SD.
Pengetahuan Pasien Rawat Inap Tentang Hak Atas Pendapat Kedua

Tabel 5

Pengetahuan Pasien Rawat Inap Tentang Hak Atas Pendapat Kedua di Rumah Sakit Umum PKU Muhammadiyah Sragen

\begin{tabular}{lcc}
\hline \multicolumn{1}{c}{ Kategori } & $\begin{array}{c}\text { Jumlah } \\
\text { Responden }\end{array}$ & Persentase (\%) \\
\hline Baik & 61 & 52 \\
Cukup & 36 & 30 \\
Kurang & 21 & 18 \\
\hline Jumlah & 118 & 100 \\
\hline
\end{tabular}

Berdasarkan tabel 5 menunjukkan bahwa pengetahuan pasien rawat inap tentang hak atas pendapat kedua di Rumah Sakit Umum PKU Muhammadiyah Sragen sebagian besar adalah kategori baik (52\%) dengan umur dewasa (26-45 tahun) dan pendidikan SMA, sedangkan sebagian kecil adalah kategori kurang (18\%) dengan umur dewasa (26-45 tahun) dan pendidikan SD/ SMP.

Pengetahuan Pasien Rawat Inap Tentang Kewajiban Pasien Terhadap Rumah Sakit

Tabel 6

Pengetahuan Pasien Rawat Inap Tentang

Kewajiban Pasien Terhadap Rumah Sakit di Rumah Sakit Umum PKU Muhammadiyah Sragen

\begin{tabular}{lcc}
\hline \multicolumn{1}{c}{ Kategori } & $\begin{array}{c}\text { Jumlah } \\
\text { Responden }\end{array}$ & Persentase (\%) \\
\hline Baik & 80 & 68 \\
Cukup & 28 & 24 \\
Kurang & 10 & 8 \\
\hline Jumlah & 118 & 100 \\
\hline
\end{tabular}

Berdasarkan tabel 4.6 menunjukkan bahwa pengetahuan pasien rawat inap tentang kewajiban pasien terhadap rumah sakit di Rumah Sakit Umum PKU Muhammadiyah Sragen sebagian besar adalah kategori baik (68\%) dengan umur dewasa (26-45 tahun) dan pendidikan SMA, sedangkan sebagian kecil adalah kategori kurang (8\%) dengan umur dewasa (26-45 tahun) dan pendidikan SD/SMP. 


\section{PEMBAHASAN}

\section{Pengetahuan Pasien Rawat Inap Tentang Hak Atas Informasi Medis}

Berdasarkan hasil penelitian terhadap gambaran pengetahuan pasien rawat inap tentang hak atas informasi medis di Rumah Sakit Umum PKU Muhammadiyah Sragen, diketahui bahwa sebagian besar adalah kategori baik (64\%) dan sebagian kecil adalah kategori kurang (13\%). Pasien berhak untuk mendapatkan informasi dari dokter tentang hal-hal yang berhubungan dengan kesehatannya. Setiap tenaga kesehatan mempunyai kewajiban memberikan informasi yang benar, jelas dan jujur mengenai kondisi kesehatan pasien. Informasi medis yang disampaikan kepada pasien meliputi penyakit yang diderita, tindakan medis yang hendak dilakukan, akibat dari tindakan medis, alternatif terapi lainnya, prognosis, dan perkiraan biaya. Hal ini sesuai dengan Undang-undang No. 36 tahun 2009 tentang Kesehatan bahwa setiap orang berhak memperoleh informasi tentang data kesehatan dirinya termasuk tindakan dan pengobatan yang telah maupun yang akan diterimanya dari tenaga kesehatan.

Terendah pada item dokter harus menjelaskan kondisi pasien tanpa harus diminta oleh pasien. Informasi medis harus disampaikan oleh tenaga kesehatan kepada pasien baik diminta atau tidak. Informasi harus diberikan secara lengkap dan jujur, kecuali dokter menilai bahwa informasi tersebut dapat merugikan kepentingan atau kesehatan pasien atau pasien menolak untuk diberikan informasi. Ketidakpahaman pasien mengenai hak atas informasi medis dikarenakan dokter tidak menjelaskan kepada pasien atau keluarganya secara langsung sebelum pasien dirawat mengenai informasi apa saja yang akan diterima pasien misalnya informasi perawatan, pengobatan dan pelayanan. Pasien sendiri hanya menerima apa saja yang sudah dijelaskan oleh dokter tentang kondisi kesehatannya kepada keluarga mereka. Dokter harus lebih menjelaskan apa saja yang menjadi hak pasien saat menjalankan pengobatan seperti informasi mengenai penyakit yang diderita oleh pasien, dimana hal ini bisa meningkatkan pengetahuan pasien terhadap hak pasien di rumah sakit.

\section{Pengetahuan Pasien Rawat Inap Tentang Hak Memberikan Persetujuan Tindakan Medis}

Berdasarkan hasil penelitian terhadap gambaran pengetahuan pasien rawat inap tentang hak memberikan persetujuan tindakan medis di Rumah Sakit Umum PKU Muhammadiyah Sragen, diketahui bahwa sebagian besar adalah kategori baik (60\%) dan sebagian kecil adalah kategori kategori kurang (15\%). Pasien berhak mendapatkan informasi tentang tindakan medis yang akan dilakukan oleh tenaga medis dan berhak untuk menyetujui ataupun menolak tindakan tersebut. Salah satu kewajiban yang harus dilakukan oleh dokter terhadap pasiennya dalam memberikan tindakan medis adalah pasien mendapatkan penjelasan secara lengkap tentang tindakan medis yang akan dilakukan oleh dokter tersebut. Untuk setiap tindakan kedokteran yang akan dilakukan oleh dokter terhadap pasiennya harus mendapat persetujuan (Informed consent), persetujuan diberikan setelah pasien mendapat penjelasan yang lengkap mengenai tindakan medis yang akan dilakukan dengan segala resikonya. Hal ini sesuai dengan PerMenKes RI No.290/ MENKES/PER/III/2008 tentang persetujuan tindakan kedokteran pasal 8 yaitu informasi medis yang perlu disampaikan kepada pasien antara lain temuan klinis dari hasil pemeriksaan medis, diagnosis penyakit, tujuan tindakan kedokteran, tata cara pelaksanaan tindakan medis, efek samping yang mungkin terjadi, alternatif tindakan lain berikut kelebihan dan kekurangannya dibandingkan dengan tindakan yang direncanakan, serta risiko dan komplikasi yang mungkin terjadi pada masingmasing alternatif tindakan.

Terendah pada item pasien berhak menolak atau menyetujui operasi yang akan dilakukan setelah dijelaskan oleh dokter. Kurangnya pemahaman pasien dikarenakan pasien tidak mengetahui kegunaan informed consent dan dalam penjelasan informasi tentang hak pasien untuk memberikan persetujuan tindakan medis kurang jelas dan dipahami oleh pasien. Informed consent merupakan hak pasien yang harus dipenuhi sebelum pasien menjalani suatu upaya medis yang akan dilakukan oleh dokter terhadap pasien, semua tindakan medis memerlukan Informed consent secara lisan maupun tertulis. Hal ini selaras dengan penelitian Yani (2011) yang menyebutkan bahwa dampak yang terjadi jika pengetahuan pasien tentang hak memberikan persetujuan kurang adalah seorang tenaga kesehatan dapat melakukan tindakan medis terhadap pasien tanpa persetujuan pasien atau keluarga. Hal ini dapat merugikan pasien atau keluarga apabila setelah dilakukannya tindakan medis menimbulkan efek samping yang merugikan pasien dan terjadinya malpraktik karena tidak adanya transaksi terapeutik antara dokter dengan pasien. 


\section{Pengetahuan Pasien Rawat Inap Tentang Hak Atas Rahasia Kedokteran}

Berdasarkan hasil penelitian terhadap gambaran pengetahuan pasien rawat inap tentang hak atas rahasia kedokteran di Rumah Sakit Umum PKU Muhammadiyah Sragen, diketahui bahwa sebagian besar adalah kategori baik (39\%) dan sebagian kecil adalah kategori kategori kurang (28\%). Pasien berhak mendapat privasi dan kerahasiaan penyakit yang diderita termasuk data-data medisnya sekalipun ia telah meninggal dunia. Setiap tenaga kesehatan wajib menyimpan rahasia kedokteran. Rahasia Kedokteran mencakup informasi mengenai identitas pasien, kesehatan pasien dan hal lain yang berkenaan dengan pasien. Pengungkapan rahasia kedokteran dapat dibuka hanya dalam kepentingan tertentu. Hal ini sesuai dengan PERMENKES RI No. 36/ MENKES/PER/III/2012 tentang Rahasia Kedokteran yang menyebutkan bahwa Rahasia kedokteran dapat dibuka hanya untuk kepentingan kesehatan pasien, memenuhi permintaan aparatur penegak hukum dalam rangka penegakan hukum, permintaan pasien sendiri, atau berdasarkan peraturan perundangundangan, dan pembukaan rahasia kedokteran dilakukan terbatas sesuai kebutuhan.

Terendah pada item untuk kepentingan penelitian, pendidikan, dan audit medis informasi medis pasien boleh dibuka sepanjang tidak menyebutkan identitas pasien. Kurangnya pemahaman pasien dikarenakan pasien tidak tahu atau tidak memahami dengan benar informasi tentang hak dan kewajiban pasien yang dipasang pada dinding bangsal perawatan saat pasien datang atau dirawat di rumah sakit. Datadata medis atau rahasia penyakit seorang pasien harus dijaga kerahasiaannya agar tidak terjadi pembocoran rahasia penyakit pasien oleh orang yang tidak bertanggungjawab yang dapat menimbulkan kerugian pasien. Hal ini selaras dengan penelitian Yani (2011) yang menyebutkan bahwa dampak yang terjadi jika pengetahuan pasien tentang hak atas rahasia kedokteran kurang adalah timbulnya pembocoran rahasia data-data medis rumah sakit oleh orang-orang yang tidak bertanggungjawab.

\section{Pengetahuan Pasien Rawat Inap Tentang Hak Atas Pendapat Kedua}

Berdasarkan hasil penelitian terhadap gambaran pengetahuan pasien rawat inap tentang hak atas pendapat kedua di Rumah Sakit Umum PKU
Muhammadiyah Sragen, diketahui bahwa sebagian besar adalah kategori baik (52\%) dan sebagian kecil adalah kategori kategori kurang (18\%). Pasien boleh meminta copy rekam medis yang mungkin akan digunakan untuk mendapatkan second opinion atau pendapat kedua, dimana copy rekam medis itu sangat dibutuhkan oleh pemiliknya. Hal ini selaras dengan penelitian Yani (2011) yang menyebutkan bahwa pengetahuan pasien tentang hak atas second opinion meliputi hak memilih dokter, hak memilih rumah sakit atau layanan medis lain dan hak mendapatkan pelayanan sesuai dengan kebutuhan medis.

Terendah pada item pasien berhak meminta konsultasi kepada dokter lain yang terdaftar di rumah sakit tersebut terhadap penyakit yang dideritanya, sepengetahuan dokter yang merawat. Kurangnya pemahaman pasien dikarenakan petugas tidak menjelaskan hak dan kewajiban pasien secara lisan. Hak dan kewajiban pasien hanya ditempelkan pada setiap dinding bangsal perawatan sehingga tidak semua pasien membacanya. Hal ini selaras dengan penelitian Yani (2011) yang menyebutkan bahwa dampak yang terjadi jika pengetahuan pasien tentang hak second opinion kurang adalah pasien menjadi tidak nyaman selama menjalani pengobatan yang dijalani masih kurang atau belum cukup karena masih ingin berkonsultasi dengan dokter lain untuk melakukan pemeriksaan lanjutan.

\section{Pengetahuan Pasien Rawat Inap tentang Kewajiban Pasien Terhadap Rumah Sakit}

Berdasarkan hasil penelitian terhadap gambaran pengetahuan pasien rawat inap tentang kewajiban pasien di Rumah Sakit Umum PKU Muhammadiyah Sragen, diketahui bahwa sebagian besar adalah kategori baik (68\%) dan sebagian kecil adalah kategori kurang (8\%). Seorang pasien dalam menerima pelayanan kesehatan tidak hanya mempunyai hak tetapi juga mempunyai kewajiban yang harus dilaksanakan seorang pasien di Rumah Sakit. Hal ini sesuai dengan Undang-undang No. 29 tahun 2004 tentang praktik kedokteran dan kedokteran gigi pasal 53 yang menyebutkan bahwa pasien dalam menerima pelayanan pada praktik kedokteran mempunyai kewajiban memberikan informasi yang lengkap dan jujur tentang masalah kesehatannya, mematuhi nasihat dan petunjuk dokter atau dokter gigi, mematuhi ketentuan yang berlaku di sarana pelayanan kesehatan dan memberikan imbalan jasa atas pelayanan yang diterima. 
Ayuk Aji Pratiwi dan Antik Pujihastuti. Gambaran Pengetahuan Tentang Hak dan Kewajiban Pasien....

Terendah pada item pasien harus memenuhi halhal yang telah disepakati atau perjanjian yang telah dibuatnya. Kurangnya pemahaman pasien dikarenakan pasien tidak membaca atau menghiraukan informasi yang tertempel di bangsal perawatan. Setiap pasien perlu dijelaskan secara langsung mengenai hak dan kewajibannya sebagai pasien. Pengetahuan yang kurang tentang kewajiban pasien di rumah sakit menyebabkan pasien tidak menaati peraturan yang ada di rumah sakit, tidak mematuhi petunjuk dokter, dan tidak jujur dalam memberikan informasi tentang penyakitnya sehingga keberhasilan pengobatan menjadi kurang maksimal. Hal ini selaras dengan penelitian Yani (2011) yang menyebutkan bahwa dampak yang terjadi jika pengetahuan pasien tentang kewajiban pasien terhadap rumah sakit kurang adalah pasien tidak mematuhi petunjuk dokter sehingga keberhasilan pengobatannya akan menjadi kurang, tidak mengetahui adanya surat-surat persetujuan tindakan medis pasien, memberikan informasi yang tidak lengkap tentang penyakitnya.

\section{SIMPULAN}

Sebesar hampir $40 \%$ pasien mempunyai pengetahuan yang kurang tentang hak dan kewajiban pasien rawat inap di rumah sakit. Disarankan pihak rumah sakit melakukan sosialisasi atau pendidikan terkait hak dan kewajiban pasien.

\section{DAFTAR PUSTAKA}

Arief M. 2008. Pengantar Metodologi Penelitian Untuk Ilmu Kesehatan. Surakarta: LPP UNS dan UNS Press.

Arikunto S. 2010. Prosedur Penelitian (Suatu Pendekatan dan Praktik). Jakarta : PT Rineka Cipta.

Departemen Kesehatan RI. 2008. Peraturan Menteri Kesehatan Republik Indonesia No.269/ MENKES/PER/III/2008 Tentang Rekam Medis. Jakarta: Menteri Kesehatan Republik Indonesia.

_. 2008. Peraturan Menteri Kesehatan Republik Indonesia No.290/MENKES/PER/III/2008 Tentang Persetujuan Tindakan Kedokteran. Jakarta: Menteri Kesehatan Republik Indonesia.
2012. Peraturan Menteri Kesehatan Republik Indonesia No.36/MENKES/PER/III/2012 Tentang Rahasia Kedokteran. Jakarta : Menteri Kesehatan Republik Indonesia.

_. 2014. Peraturan Menteri Kesehatan Republik Indonesia No.69/MENKES/PER/III/2014 Tentang Kewajiban Rumah Sakit dan Kewajiban Pasien. Jakarta : Menteri Kesehatan Republik Indonesia.

Hardiwinoto dr. 2011. Kategori Umur dalam http://ilmu-kesehatan-masyarakat.blogspot. com/2012/05/kategori-umur.html. Diakses : 01 Mei 2018 Jam 10.56 WIB.

Magdalena EL. 2014. Tingkat Pengetahuan Pasien Rawat Inap Tentang Sistem Pembayaran Melalui Badan Penyelenggara Jaminan Sosial (BPJS) Kesehatan di RSUD Sukoharjo Tahun 2014. [Karya Tulis Ilmiah]. Karanganyar : STIKes Mitra Husada.

Mubarak WI. 2011. Promosi Kesehatan Untuk Kebidanan. J1. Raya Lenteng Agung No.101 Jagakarsa, Jakarta 12610.

Notoatmodjo S. 2010. Metodologi Penelitian Kesehatan. Jakarta: PT Rineka Cipta.

. 2012. Promosi Kesehatan Teori \& Aplikasi. Jakarta: PT Rineka Cipta.

Nursalam. 2008. Konsep dan Penerapan Metodologi Penelitian Ilmu Keperawatan Edisi 2. Jakarta: Salemba Medika.

Peraturan Pemerintah Nomor 10 Tahun 1966 tentang Wajib Simpan Rahasia Kedokteran.

Sugiyono. 2010. Metode Penelitian Pendidikan. Bandung: Alfabeta.

Undang-Undang Republik Indonesia No. 29 tahun 2004 tentang Praktik Kedokteran.

_No. 36 tahun 2009 tentang Kesehatan.

_No. 44 Tahun 2009 tentang Rumah Sakit.

Yani. 2011. Tingkat Pengetahuan Pasien Tentang Hak Dan Kewajiban Pasien Atas Informasi Medis Pasien Rawat Inap Kelas III Di Rumah Sakit PKU Muhammadiyah Karanganyar Tahun 2011. [Karya Tulis Ilmiah]. Karanganyar : STIKes Mitra Husada.

Wijono D. 2000. Manajemen Mutu Pelayanan Kesehatan. Surabaya: Airlangga University Press. 